\title{
Prototypical Peripheral Toponym Pairs Expressing the Concept 'All Over the Country' as a Part of the Mental Map
}

\author{
Riemer Reinsma ${ }^{1}$
}

Received: 17 May 2019 / Accepted: 3 August 2019 / Published online: 20 August 2019

(c) The Author's 2019, corrected publication 2019

\begin{abstract}
Expressing the concept 'all over the country' by mentioning one or more name pairs is a well-known phenomenon. A Dutch example is 'Van Delfzijl tot Maastricht', Delfzijl being situated in the extreme north of the country, Maastricht in the south. Such expressions are not only used on the national level, but also on subnational (for example, provinces) and supranational levels. Obviously, they arise spontaneously, many of them being preceded (or followed) by phrases like "overal in Nederland" [all over the Netherlands]; it is improbable indeed that anyone would first turn to an atlas or map before creating them. This paper departs from the idea that, if a country (etc.) has oblong contours, toponym pairs may preferably be chosen which are most distant from each other; this would illustrate 'ubiquity' better than choosing shorter ones. It focuses on the Netherlands and will deal, among others, with the following questions: (1) Which toponyms are most 'popular', and why? (2) If toponyms refer to cities and towns, does their 'popularity' correlate with a high population, with news coverage, or both? (3) Is there a preference for any combination of compass directions, for example, for cardinal points (contrary to ordinal ones)? And if so, is the combination of compass directions concerned associated with the longitudinal direction (if the country concerned has oblong contours)? (4) Is there a fixed pattern in the direction expressed by the name order within name pairs? It is, for example, conceivable that there is a tendency to prefer $\mathrm{N}-\mathrm{S}$ to $\mathrm{S}-\mathrm{N}$, considering the prominent position of the northern compass point.
\end{abstract}

Keywords Cardinal compass points $\cdot$ Estimated distances $\cdot$ Mental map $\cdot$ Newspaper coverage $\cdot$ Oblong contours $\cdot$ Ordinal compass points $\cdot$ Prototypical toponyms $\cdot$ Provincial Capitals $\cdot$ Randstad $\cdot$ Toponym pairs $\cdot$ Ubiquity

\section{Zusammenfassung}

Die Umsetzung des Konzepts ,,all over the country“ durch das Erwähnen eines oder mehrerer Namenspaare ist ein weit verbreitetes Phänomen. Ein niederländisches Beispiel ist „Van Delfzijl tot Maastricht“: Delfzijl liegt sehr nördlich im Land, während sich Maastricht im Süden befindet. Solche Bezeichnungen werden nicht nur auf nationaler, sondern auch auf subnationaler (z.B. Provinzen) und supranationaler Ebene eingesetzt. Offensichtlich erwachsen diese Bezeichnungen spontan. Viele von ihnen werden begleitet von Phrasen wie „overal in Nederland” [überall in den Niederlanden]; es ist unwahrscheinlich, dass jemand erst einen Atlas oder eine Karte zu Rate zieht, bevor der Name kreiert wird. Dieser Artikel fußt auf der Idee, dass Toponympaare vorzugsweise anhand der größten Distanz voneinander gewählt werden, sofern ein Land (etc.) längliche Konturen aufweist. Dies illustriert Allgegenwärtigkeit mehr als die Bildung (räumlich) kürzerer Paare. Der Aufsatz konzentriert sich auf die Niederlande und er behandelt, u.a., folgende Fragen: (1) Welche Toponyme sind am ,beliebtesten', und warum? (2) Falls sich Toponyme auf Städte bzw. Kleinstädte beziehen, korreliert dann ihre ,Popularität‘ mit einer hohen Bevölkerungszahl, mit Berichterstattung, oder mit beidem? (3) Gibt es eine Bevorzugung für eine Kombination von Kompassrichtungen, z.B. für kardinale Punkte (im Gegensatz zu ordinalen)? Und falls ja, steht die Kombination aus betroffenen Kompassrichtungen im Zusammenhang mit der longitudinalen Richtung (sofern das Land längliche Konturen hat)? (4) Existiert ein festes Muster hinsichtlich der Richtung, die durch den Namenreihenfolge innerhalb von Namenpaaren ausgedrückt wird? Es ist beispielsweise denkbar, dass es eine Bevorzugungstendenz von N-S gegenüber S-N gibt aufgrund der auffälligen Position des nördlichen Kompasspunkts. (5) Gibt es eine Präferenz bezogen auf die Abfolge, in der Elemente in Namenpaaren auftreten?

Riemer Reinsma

rr@riemerreinsma.nl

http://www.riemerreinsma.nl/

$1 \quad$ Amsterdam, Netherlands 


\section{Introduction}

Expressing the concept 'all over the country' by mentioning one or more name pairs is a widespread phenomenon. A Dutch example is 'Van Delfzijl tot Maastricht', Delfzijl being situated in the extreme north of the country, Maastricht in the south (Fig. 1) (Source: https://de.wikipedia.org/ wiki/Das_Lied_der_Deutschen\#/media/File:Maas_memel _etsch_belt.svg). No less than two name pairs occur in Heinrich Hoffmann von Fallersleben's Lied der Deutschen (1841): "Von der Maas bis an die Memel,/Von der Etsch bis an den Belt/Deutschland, Deutschland über alles" (Fig. 2). An American counterpart is in a song by Woody Guthrie: "This land is my land, this land is your land/From California to the New York Island", etc. Combinations of three name pairs have also been found.
Such expressions are not only used on the national level, but also on subnational and supranational levels (for example, provinces and continents), or in non-administrative areas, like the Flemish-Dutch language area ("Van Delfzijl tot Kortrijk"). A carnival song in the Dutch province of Limburg (Fig. 3) contains the following lines: "Vaan Eijsde tot de Mookerheij,/Lop eederein te zinge." [From Eijsden to the Mookerhei everybody is singing].

This paper departs from the idea that utterances like the ones just mentioned result from a 'sense of place', the feelings people cherish with regard to their territory (see Walmsley and Lewis 1993: 118-121).

Until now, attention has been paid mostly to the mental map as a means to navigate: in neighborhoods, cities, etc. This paper examines, however, how the mental map may serve as a means to express 'ubiquity' within the framework

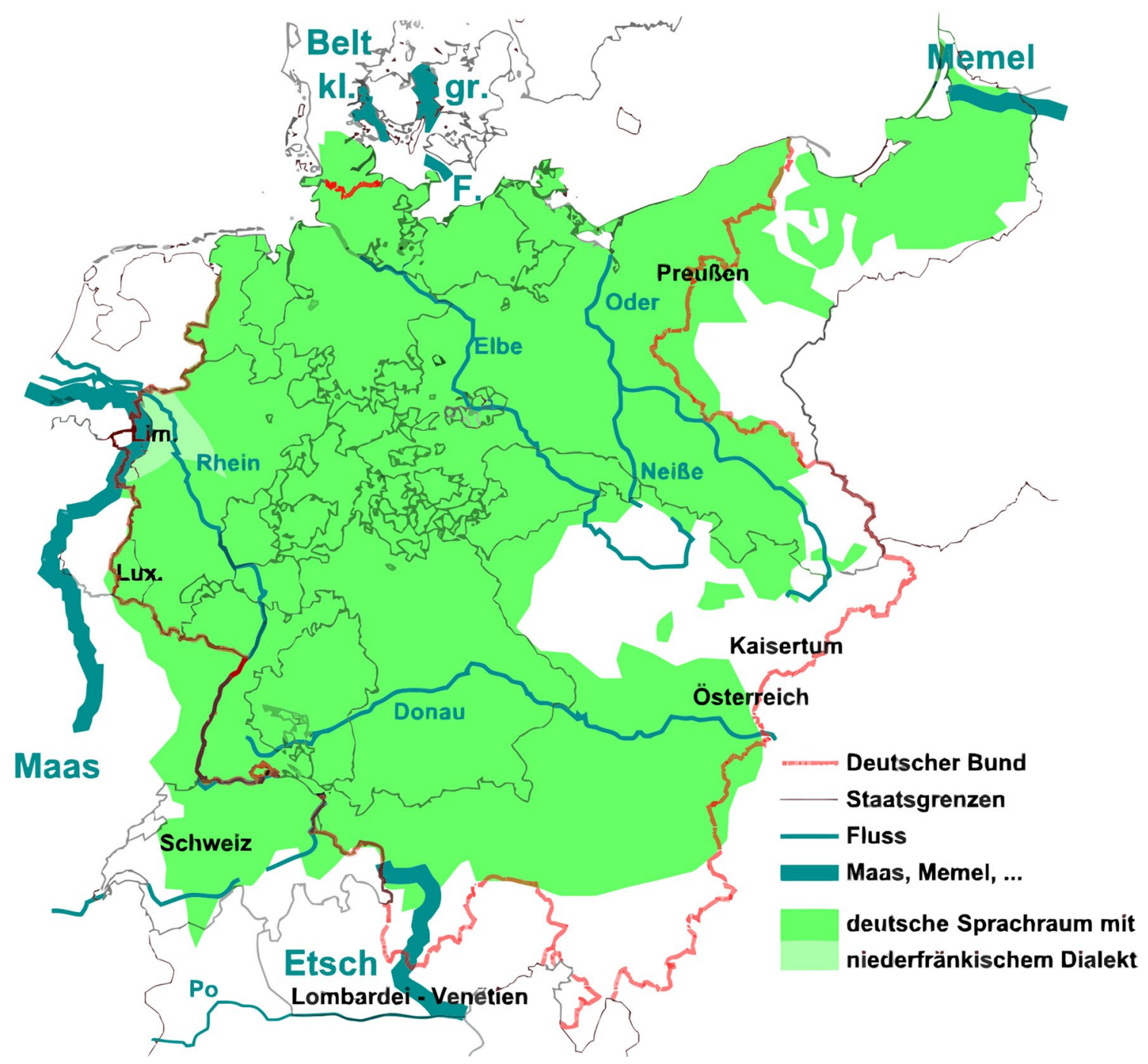

Fig. 1 German peripheral locations in the Deutschlandlied 


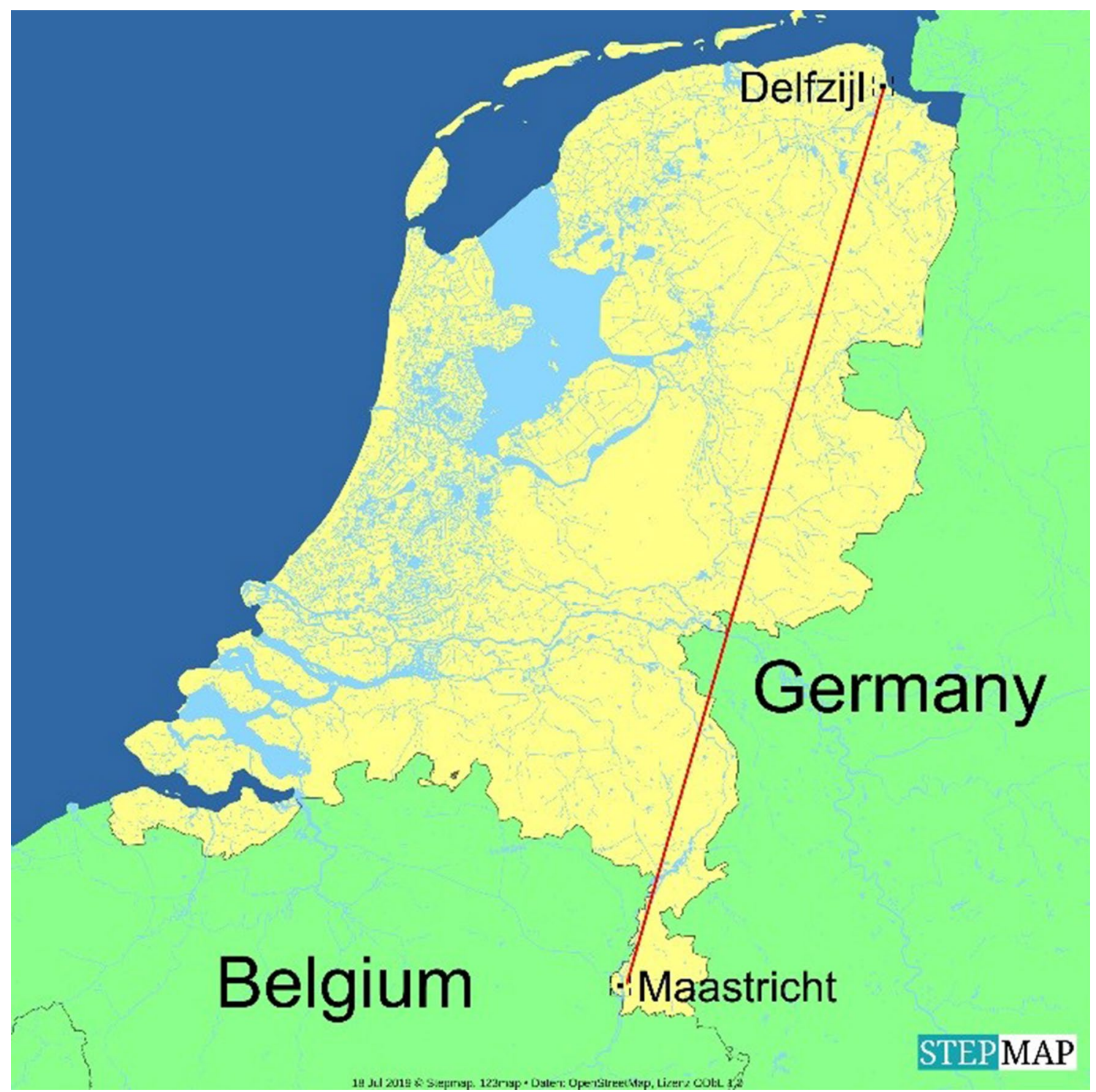

Fig. 2 Dutch peripheral locations Delfzijl and Maastricht

of a state, using names in the national periphery. The periphery, here, is not the zone where the national sentiment is at its weakest or at least weakening, it is just the zone where it stops. It is the border zone that delimits the nation as a whole.

Cognitive mapping has been defined (Kitchin and Stewart Fotheringham 1997, 278, with reference to Downs and Stea 1973, 8-26) as "the study of how we consciously, and more commonly unconsciously, acquire, learn, develop, think about and store data relating to our everyday geographic environment" (italicization by RR). Obviously, no "collective', shared-by-all mental map exists: some people have mental maps of a geographical nature, others dispose of photograph-like mental images. The present study assumes that, within the variety of possible mental maps concerning the concept 'all over the country', certain biases and trends can be discovered.

Mental map literature varies largely in the scale size of the experiments. Cadwallader (1976) remarks that subjects who make distance estimates within cities were requested to mention walking distances, while distances between cities are expressed as the crow flies; in the latter case, conclusions may be relevant to the present study. Pocock and Hudson (1978) state that cognitive distances between cities are independent from questioned vehicles, travel time or straight line distance. MacEachren (1980: 30) supports this conclusion, maintaining that travel time predicts subjective distance better if it comes to judgments on intra-urban distances, and thus suggesting that the mental map, on a larger scale, is based on straight line distances. 


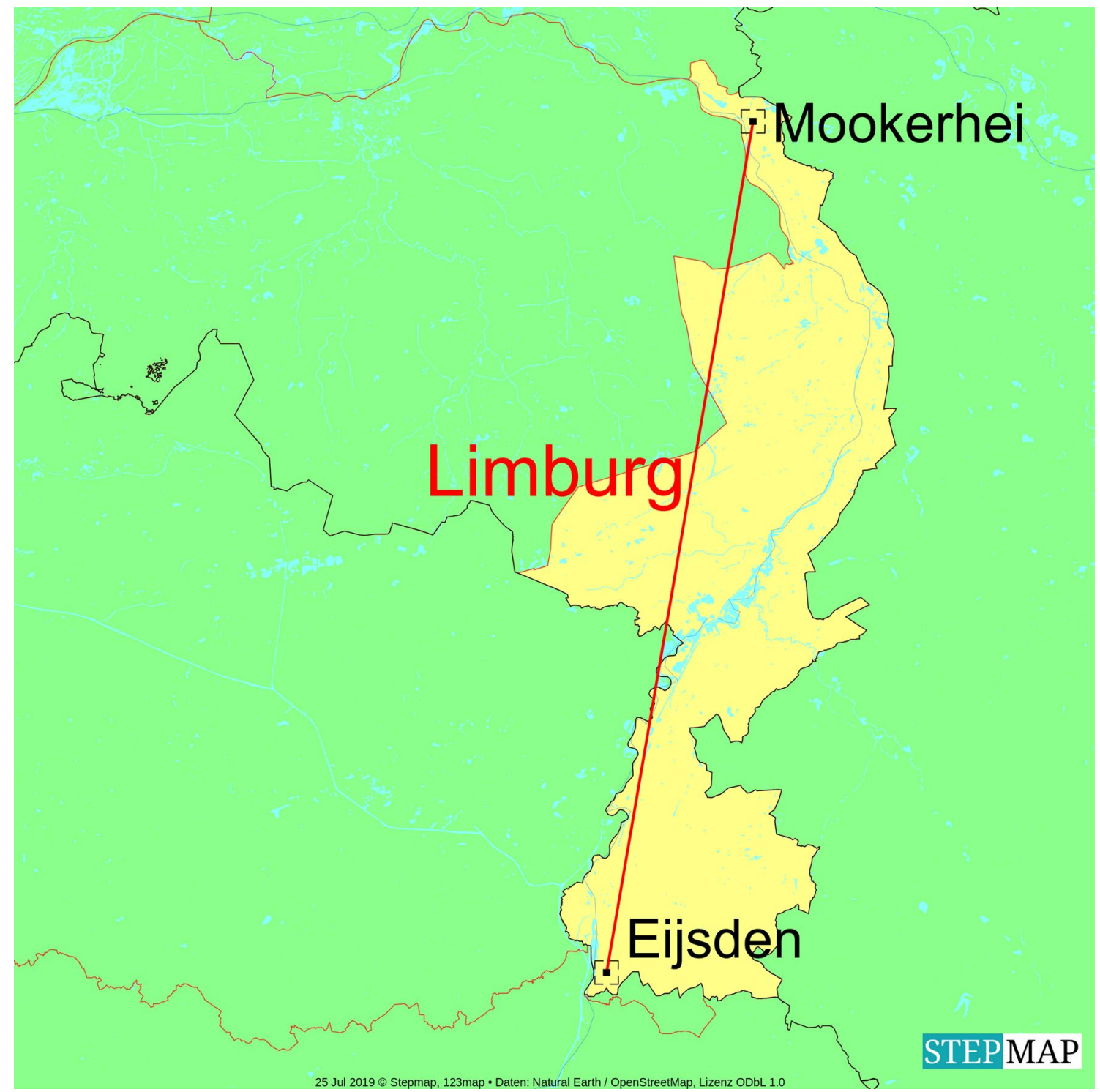

Fig. 3 Peripheral locations of the province of Limburg

Distance estimates may also be influenced by the presence of landmarks and so-called barriers. Sadalla, Burroughs \& Staplin (1980: 516) found that the presence of landmarks tends to enlarge distance estimates. Landmarks are described as "strategic foci to and from which an individual travels". The term "has been used to denote (a) discriminable features of a route, which signal navigational decisions"; (b) discriminable features of a region, which allow a subject to maintain a general geographical orientation, and (c) salient information in a memory task". This finding would militate the hypothesis that distance estimates like the ones examined in this study are not in a straight line. One may, however, object that expressions like 'Van Delfzijl tot Maastricht' must be supposed to arise spontaneously, which eliminates the possibility that the clutter hypothesis might lead to distance distortions, in the sense that the presence of 'barriers' might enlarge cognitive distances.

Which part do compass directions play? Maki et al. (1977) asked college students to verify the truth of displays containing name pairs of US states which were positioned either east-west from each other, or north-south. Judgments concerning north-east name pairs were faster than the east-west pairs. This confirmed the authors' intuitions: "one tends to name compass points as 'north, south, east, west', perhaps since real maps tend to be oriented with respect to the north." The prominence of the north compass direction was evident from an experiment in which 20 undergraduates were asked to "write the names of the four major compass points". All subjects wrote north first. Tversky (1981, 415-416) found that subjects have a preference for map 
Table 1 Toponym pairs

\begin{tabular}{|c|c|c|}
\hline From & To & Distance $(\mathrm{km})$ \\
\hline 1. Achterhoek (Gl) & Zeeland & 196 \\
\hline \multirow[t]{2}{*}{ 2. Alkmaar (NH) } & Voerendaal (L) & 211 \\
\hline & Zevenaar (Gl) & 119 \\
\hline 3. Almelo (O) & Leiden $(\mathrm{ZH})$ & 149 \\
\hline \multirow[t]{9}{*}{ 4. Amsterdam (NH) } & Delfzijl (Gr) & 172 \\
\hline & Echt (L) & 156 \\
\hline & Enschede (O) & 137 \\
\hline & Genemuiden $(\mathrm{O})$ & 98 \\
\hline & Limburg & 208 \\
\hline & Maastricht (L) & 178 \\
\hline & Schin op Geul (L) & 182 \\
\hline & Zeeland & 121 \\
\hline & South Limburg & 185 \\
\hline 5. Apel, Ter (Gr) & Bergen aan Zee $(\mathrm{NH})$ & 159 \\
\hline \multirow[t]{3}{*}{ 6. Appelscha (Fr) } & Maastricht (L) & 238 \\
\hline & Schin op Geul (L) & 235 \\
\hline & Terneuzen (Z) & 249 \\
\hline \multirow[t]{4}{*}{ 7. Appingedam (Gr) } & Amsterdam (NH) & 169 \\
\hline & Heerlen (L) & 277 \\
\hline & Schin op Geul (L) & 282 \\
\hline & Veghel (NB) & 209 \\
\hline 8. Assen (D) & Maastricht (L) & 245 \\
\hline 9. Bergen op Zoom (NB) & Venlo (L) & 131 \\
\hline \multirow[t]{6}{*}{ 10. Breda (NB) } & Amswterdam (NH) & 88 \\
\hline & Enschede $(\mathrm{O})$ & 162 \\
\hline & Groningen (city; Gr) & 220 \\
\hline & Nieuweschans (Gr) & 243 \\
\hline & Venray (L) & 83 \\
\hline & Winschoten (Gr) & 233 \\
\hline \multirow[t]{3}{*}{ 11. Breskens ( $\mathrm{Z})$} & Delfzijl (Gr) & 314 \\
\hline & Groningen (city; Gr) & 288 \\
\hline & Hoogezand (Gr) & 293 \\
\hline \multirow[t]{3}{*}{ 12. Cadzand (Z) } & Appingedam (Gr) & 319 \\
\hline & Roodeschool (Gr) & 322 \\
\hline & Veluwe & 186 \\
\hline 13. Delft (ZH) & Enschede (O) & 174 \\
\hline \multirow[t]{13}{*}{ 14. Delfzijl (Gr) } & Cadzand (Z) & 323 \\
\hline & Goes $(Z)$ & 288 \\
\hline & Maasbracht (L) & 253 \\
\hline & Maastricht (L) & 288 \\
\hline & Middelburg (Z) & 302 \\
\hline & Schin op Geul (L) & 285 \\
\hline & Terneuzen $(\mathrm{Z})$ & 305 \\
\hline & Vaals (L) & 291 \\
\hline & Valkenburg [L] & 284 \\
\hline & Venlo (L) & 224 \\
\hline & Vlissingen $(\mathrm{Z})$ & 384 \\
\hline & Zeeland & 291 \\
\hline & Zierikzee (Z) & 276 \\
\hline \multirow[t]{2}{*}{ 15. Doetinchem (Gl) } & Kerkrade (L) & 123 \\
\hline & Westkapelle (Z) [“Westkappelle"] & 202 \\
\hline
\end{tabular}


Table 1 (continued)

\begin{tabular}{|c|c|c|}
\hline From & To & Distance $(\mathrm{km})$ \\
\hline \multirow[t]{6}{*}{ 16. Dokkum (Fr) } & Cadzand $(Z)$ & 280 \\
\hline & Hulst (Z) & 263 \\
\hline & Maastricht (L) & 276 \\
\hline & Middelharnis (ZH) & 214 \\
\hline & Zeeuws-Vlaanderen & 267 \\
\hline & Zierikzee (Z) & 233 \\
\hline \multirow[t]{3}{*}{ 17. Drenthe } & Limburg & 263 \\
\hline & Venlo (L) & 178 \\
\hline & Zeeland & 249 \\
\hline 18. Drielandenpunt & Zoutkamp (Gr) & 289 \\
\hline 19. Egmond (NH) & Doetinchem $(\mathrm{Gl})$ & 135 \\
\hline 20. Eijsden (L) & Ameland (Fr) & 296 \\
\hline \multirow[t]{3}{*}{ 21. Eindhoven (NB) } & Bergen op Zoom (NB) & 82 \\
\hline & Groningen (city; Gr) & 211 \\
\hline & Middelburg (Z) & 266 \\
\hline 22. Enschede $(\mathrm{O})$ & Volendam (NH) & 127 \\
\hline \multirow[t]{6}{*}{ 23. Friesland } & Achterhoek & 139 \\
\hline & Brabant & 191 \\
\hline & Limburg & 220 \\
\hline & Maastricht (L) & 257 \\
\hline & Tilburg (NB) & 182 \\
\hline & Zeeland & 227 \\
\hline 24. Geleen (L) & Alkmaar (NH) & 199 \\
\hline \multirow[t]{2}{*}{ 25. Goes (Z) } & Groningen (city; Gr) & 263 \\
\hline & Staphorst (O) & 202 \\
\hline \multirow[t]{25}{*}{ 26. Groningen [city, Gr] } & Amsterdam (NH) & 147 \\
\hline & Bergen op Zoom (NB) & 246 \\
\hline & Breda (NB) & 220 \\
\hline & Geertruidenberg (NB) & 205 \\
\hline & Geleen (L) & 255 \\
\hline & Goes $(\mathrm{Z})$ & 263 \\
\hline & 's-Hertogenbosch (“Den Bosch”) (NB) & 189 \\
\hline & Kerkrade (L) & 264 \\
\hline & Laren $(\mathrm{NH})$ & 140 \\
\hline & Maastricht (L) & 270 \\
\hline & Middelburg (Z) & 277 \\
\hline & Nijmegen (Gl) & 164 \\
\hline & Oss (NB) & 177 \\
\hline & Rotterdam (ZH) & 201 \\
\hline & Stavenisse $(\mathrm{Z})$ & 251 \\
\hline & Terneuzen (Z) & 280 \\
\hline & Zierikzee $(\mathrm{Z})$ & 250 \\
\hline & Limburg & 292 \\
\hline & North Brabant (“Brabant”) & 213 \\
\hline & North Holland & 129 \\
\hline & Westerschelde & 280 \\
\hline & Zeeland & 266 \\
\hline & Zeeuws-Vlaanderen & 276 \\
\hline & Zuid-Holland & 193 \\
\hline & South Limburg & 267 \\
\hline
\end{tabular}


Table 1 (continued)

\begin{tabular}{|c|c|c|}
\hline From & To & Distance $(\mathrm{km})$ \\
\hline 27. Haarlem (NH) & Eindhoven (NB) & 119 \\
\hline \multirow[t]{7}{*}{ 28. Hague, The (ZH) } & Arnhem $(\mathrm{Gl})$ & 109 \\
\hline & Den Helder (NH) & 103 \\
\hline & Emmen (D) & 193 \\
\hline & Enschede (O) & 177 \\
\hline & Groningen (city; Gr) & 199 \\
\hline & Veendam $(\mathrm{Gr})$ & 208 \\
\hline & Heerlen (L) & 230 \\
\hline \multirow[t]{2}{*}{ 29. Heerlen (L) } & Ameland (Fr) & 284 \\
\hline & Groningen (city; Gr) & 262 \\
\hline \multirow[t]{6}{*}{ 30. Helder, Den (NH) } & Kerkrade (L) & 249 \\
\hline & Maastricht (L) & 242 \\
\hline & Montfort (L) & 219 \\
\hline & Vaals (L) & 257 \\
\hline & Valkenburg [L] & 244 \\
\hline & Zevenaar (Gl) & 145 \\
\hline \multirow[t]{3}{*}{ 31. Hengelo (O) } & Middelburg (Z) & 234 \\
\hline & Scheveningen $(\mathrm{ZH})$ & 170 \\
\hline & Vinkeveen (U) & 126 \\
\hline \multirow[t]{2}{*}{ 32. Hook of Holland (ZH) } & Oldenzaal (O) & 194 \\
\hline & Den Helder NH) & 116 \\
\hline 33. Hoorn $(\mathrm{NH})$ & Balkbrug (O) & 90 \\
\hline 34. Hulst (Z) & Winschoten $(\mathrm{Gr})$ & 290 \\
\hline \multirow[t]{2}{*}{ 35. IJmuiden (NH) } & Maastricht (L) & 193 \\
\hline & Tolkamer (Gl) & 122 \\
\hline 36. Katwijk (aan Zee) (ZH) & Snakkerburen (Fr) & 147 \\
\hline \multirow[t]{2}{*}{ 37. Kerkrade (L) } & Groningen (city; Gr) & 264 \\
\hline & Den Helder (NH) & 249 \\
\hline \multirow[t]{2}{*}{ 38. Klazienaveen (D) } & Medemblik (NH) & 126 \\
\hline & Schin op Geul (L) & 221 \\
\hline \multirow[t]{6}{*}{ 39. Leeuwarden (Fr) } & Amsterdam (NH) & 111 \\
\hline & Limburg & 287 \\
\hline & Maastricht (L) & 261 \\
\hline & Middelburg (Z) & 240 \\
\hline & Roermond (L) & 224 \\
\hline & Sas van Gent (Z) & 258 \\
\hline \multirow[t]{5}{*}{ 40. Limburg } & Achterhoek & 161 \\
\hline & Friesland & 283 \\
\hline & Groningen [province] & 292 \\
\hline & Leeuwarden $(\mathrm{Fr})$ & 287 \\
\hline & Zuid-Holland & 185 \\
\hline \multirow[t]{10}{*}{ 41. Maastricht (L) } & Bergen op Zoom (NB) & 121 \\
\hline & Delfzijl (Gr) & 288 \\
\hline & Drenthe & 270 \\
\hline & Groningen (city; Gr) & 270 \\
\hline & Den Helder NH) & 242 \\
\hline & Hemelumer Oldeferd (Fr) & 229 \\
\hline & Hook of Holland (ZH) & 165 \\
\hline & Leeuwarden (Fr) & 261 \\
\hline & Meppel (D) & 207 \\
\hline & Nigtevegt (U) & 164 \\
\hline
\end{tabular}


Table 1 (continued)

\begin{tabular}{|c|c|c|}
\hline From & To & Distance $(\mathrm{km})$ \\
\hline & Surhuisterveen (Fr) & 262 \\
\hline & Terschelling (Fr) & 284 \\
\hline & Vlagtwedde (Gr) & 261 \\
\hline & Vlieland (Fr) & 275 \\
\hline & Warfhuizen (Gr) & 281 \\
\hline 42. Medemblik (NH) & Enschede $(\mathrm{O})$ & 135 \\
\hline \multirow[t]{2}{*}{ 43. Meppel (D) } & Terneuzen $(\mathrm{Z})$ & 221 \\
\hline & Zierikzee (Z) & 193 \\
\hline \multirow[t]{4}{*}{ 44. Middelburg (Z) } & Friesland & 236 \\
\hline & Groningen (city; Gr) & 277 \\
\hline & Poppenwier (Fr) & 248 \\
\hline & Sint Nicolaasga (Fr) & 230 \\
\hline 45. Nijmegen (Gl) & Hellevoetsluis $(\mathrm{ZH})$ & 117 \\
\hline 46. North Brabant ("Brabant”) & Friesland & 191 \\
\hline \multirow[t]{2}{*}{ 47. Oldenzaal (O) } & Katwijk aan Zee $(\mathrm{ZH})$ & 171 \\
\hline & Vlissingen $(Z)$ & 249 \\
\hline 48. Paterswolde (D) & Limburg & 284 \\
\hline 49. Pingjum (Fr) & Tegelen (L) & 202 \\
\hline \multirow[t]{2}{*}{ 50. Retranchement (Z) } & Dollard (Gr) & 335 \\
\hline & Hongerige Wolf $(\mathrm{Gr})$ & 329 \\
\hline \multirow[t]{2}{*}{ 51. Roermond (L) } & Groningen (city; Gr) & 229 \\
\hline & Zeeland & 153 \\
\hline \multirow[t]{8}{*}{ 52. Roodeschool (Gr) } & Goes $(\mathrm{Z})$ & 288 \\
\hline & Gulpen (L) & 296 \\
\hline & Maastricht (L) & 295 \\
\hline & Retranchement (Z) & 325 \\
\hline & Sluis $(\mathrm{Z})$ & 328 \\
\hline & Terneuzen $(\mathrm{Z})$ & 306 \\
\hline & Vaals (L) & $298^{\mathrm{a}}$ \\
\hline & Vlissingen (Z) & 307 \\
\hline \multirow[t]{2}{*}{ 53. Rotterdam (ZH) } & Assen (D) & 184 \\
\hline & Pieterburen (Gr) & 211 \\
\hline \multirow[t]{2}{*}{ 54. Sappemeer (Gr) } & Cadzand (Z) & 305 \\
\hline & Ohé en Laak (L) & 238 \\
\hline \multirow[t]{6}{*}{ 55. Schiermonnikoog (Fr) } & Limburg & 238 \\
\hline & Maastricht (L) & 294 \\
\hline & Vaals (L) & 301 \\
\hline & Valkenburg (L) & 291 \\
\hline & Zierikzee (Z) & 253 \\
\hline & South Limburg & 293 \\
\hline 56. Schin op Geul (L) & Groningen (city; Gr) & 267 \\
\hline 57. Sneek (Fr) & Rotterdam (ZH) & 147 \\
\hline 58. South Limburg & Amsterdam-Zuid & 218 \\
\hline 59. Stadskanaal (Gr) & Amsterdam-Zuidoost & 153 \\
\hline \multirow[t]{2}{*}{ 60. Terneuzen $(\mathrm{Z})$} & Groningen (city; Gr) & 280 \\
\hline & Roodeschool (Gr) & $305^{\mathrm{b}}$ \\
\hline \multirow[t]{3}{*}{ 61. Terschelling (Fr) } & Limburg & 249 \\
\hline & Maastricht (L) & 284 \\
\hline & South Limburg & 287 \\
\hline
\end{tabular}


Table 1 (continued)

\begin{tabular}{|c|c|c|}
\hline From & To & Distance $(\mathrm{km})$ \\
\hline \multirow[t]{5}{*}{ 62. Texel (NH) } & Heerlen (L) & 254 \\
\hline & Maastricht (L) & 252 \\
\hline & Vaals (L) & 295 \\
\hline & Venlo (L) & 232 \\
\hline & South Limburg & 263 \\
\hline 63. Uithuizen (Gr) & Waterlandkerkje (Z) & 313 \\
\hline 64. Uithuizermeeden (Gr) & Schin op Geul (L) & 290 \\
\hline \multirow[t]{5}{*}{ 65. Vaals (L) } & Delfzijl (Gr) & 291 \\
\hline & Helder, Den (NH) & 257 \\
\hline & Pingjum (Fr) & 263 \\
\hline & Roodeschool (Gr) & 299 \\
\hline & Winschoten (Gr) & 272 \\
\hline \multirow[t]{2}{*}{ 66. Veendam $(\mathrm{Gr})$} & Maastricht (L) & 263 \\
\hline & Venlo (L) & 199 \\
\hline 67. Veenendaal (U) & Maastricht (L) & 131 \\
\hline 68. Veghel (NB) & Harderwijk (Gl) & 81 \\
\hline \multirow[t]{3}{*}{ 69. Venlo (L) } & Oldeberkoop (Fr) & 174 \\
\hline & Texel (NH) & 209 \\
\hline & Vlissingen (Z) & 180 \\
\hline 70. Venray (L) & Amsterdam (NH) & 120 \\
\hline 71. Vlagtwedde (Gr) & Schin op Geul (L) & 256 \\
\hline \multirow[t]{3}{*}{ 72. Vlieland (Fr) } & North Brabant ("Brabant”) & 198 \\
\hline & Eijsden $(\mathrm{L})$ & 283 \\
\hline & Maastricht (L) & 275 \\
\hline 73. Vlissingen $(\mathrm{Z})$ & Groningen (city, Gr) & 283 \\
\hline \multirow[t]{2}{*}{ 74. Volendam $(\mathrm{NH})$} & Cadzand [“katzand”] (Z) & 169 \\
\hline & Hilversum $(\mathrm{NH})$ & 30 \\
\hline 75. Waddenzee & Zeeuws-Vlaanderen & 267 \\
\hline \multirow[t]{2}{*}{ 76. Wassenaar (ZH) } & Heerlen (L) & 177 \\
\hline & Hoogezand (Gr) & 195 \\
\hline 77. Winschoten (Gr) & Heerlen (L) & 261 \\
\hline 78. Winterswijk (Gl) & Heerlen (L) & 131 \\
\hline \multirow[t]{6}{*}{ 79. Zeeland } & Ameland (Fr) & 249 \\
\hline & Apel, Ter (Gr) & 268 \\
\hline & Enschede $(\mathrm{O})$ & 224 \\
\hline & Friesland & 227 \\
\hline & Groningen (prov) & 266 \\
\hline & Midden-Limburg & 148 \\
\hline \multirow[t]{4}{*}{ 80. Zierikzee $(\mathrm{Z})$} & Assen (D) & 233 \\
\hline & Joure ("Jouwere") (Fr) & 194 \\
\hline & Klazienaveen (D) & 241 \\
\hline & Roodeschool (Gr) ("Rodeschool”) & 275 \\
\hline 81. Zwolle (O) & Middelburg (Z) & 203 \\
\hline
\end{tabular}

Province name abbreviations: D Drenthe, Fr Friesland, Gl Gelderland, Gr Groningen, L Limburg, NB North Brabant, NH North Holland, O Overijssel, U Utrecht (prov.), Z Zeeland, ZH South Holland

${ }^{\mathrm{a}} \mathrm{www}$.afstanden.com

${ }^{\mathrm{b}}$ www.afstanden.com 
Table 2 Most frequent peripheral toponyms (>10 times attested) in name pairs expressing ubiquity

\begin{tabular}{llll}
\hline Toponym & $\begin{array}{l}\text { Frequency in } \\
\text { name pairs }\end{array}$ & $\begin{array}{l}\text { Initial posi- } \\
\text { tion }\end{array}$ & $\begin{array}{l}\text { Final } \\
\text { position }\end{array}$ \\
\hline 1. Maastricht & 150 & 22 & 128 \\
2. Groningen (city) & 107 & 64 & 43 \\
3. Limburg & 91 & 16 & 75 \\
4. Groningen (province) & 97 & 46 & 51 \\
5. Friesland & 43 & 22 & 21 \\
6. Delfzijl & 41 & 37 & 4 \\
7. Zeeland & 38 & 19 & 19 \\
8. Den Helder & 30 & 16 & 14 \\
9. Amsterdam & 27 & 18 & 9 \\
10. Roodeschool & 19 & 12 & 7 \\
11. Leeuwarden & 18 & 12 & 6 \\
12. Vaals & 16 & 7 & 9 \\
13. Middelburg & 15 & 7 & 8 \\
14. Terneuzen & 14 & 2 & 12 \\
15. Zuid-Limburg & 13 & 8 & 5 \\
16. Cadzand & 12 & 4 & 8 \\
17. Dokkum & 11 & 11 & - \\
18. Heerlen & 11 & 5 & 6 \\
\hline
\end{tabular}

orientations in terms of cardinal compass directions $(\mathrm{N}-\mathrm{S}$, $\mathrm{E}-\mathrm{W})$, as a simplification of ordinal compass directions like NW-SE.

The focus is on the Netherlands and its present situation. Only single name pairs are examined, leaving combinations of two or more pairs aside. Willemstad, the capital of Curaçao (having a country status within the Kingdom of the Netherlands), mentioned one time, has been left aside.

\section{Problem}

First, an inventory will be made of categories of geographic features occurring in name pairs. Which of them are deemed most prototypical on the mental map if the concept of 'ubiquity' is involved, and why? Second, a few questions may arise with regard to the directions in name pairs, in terms of compass points. Does the mental map prefer cardinal compass points to ordinal ones? Is there a preference for any combination of compass points, for example, for cardinal directions (instead of ordinal ones)? And if so, are the combinations of compass points concerned associated with the longitudinal direction (if the country concerned has oblong contours, like the Netherlands)? One may expect that if a country has oblong contours, there would be a preference for the longest possible line between the extremities; this would illustrate 'ubiquity' better than choosing a shorter axis.
The name order in name pairs, too, will be examined. Does the mental map prefer a fixed pattern in the name order within name pairs? For example, is there a clear tendency to prefer north-south to south-north, considering the prominence of the northern compass point?

And finally, if toponyms refer to residential nuclei, does their prototypicality correlate with the size of their population, or with their news coverage?

\section{Methods}

Toponyms were collected by means of co-occurrence analysis. Based on a given toponym Delfzijl (well known in the Netherlands as a northern near-border toponym and as such often related to Maastricht in the south, but sometimes related to other southern toponyms), toponym pairs have been collected by means of LexisNexis Academic (selection: national newspapers). Search words were "van [toponym A] tot" (i.e., from [toponym A] to [toponym B]). For example, the search "van Delfzijl tot" generated, among others, Maastricht ("van Delfzijl tot Maastricht"), which in its turn generated, among others, Den Helder ("van Maastricht tot Den Helder"), and so on. This process was continued until no more new toponyms showed up.

Subsequently, straight line distances between names in toponym pairs were measured from http://nl.afstandmeten.himmera.com/afstand_tussen-vaals-delfzijl-meten _routeplanner_wegenkaart_km-59500.html. This database is, however, not infallible. In a few cases, www.afsta nden.com had to furnish correct distances. In another few cases, neither database succeeded in mentioning the correct distance. Distances to Zeeuws-Vlaanderen (occurring in the name pairs Dokkum-Zeeuws-Vlaanderen and Groningen-Zeeuws-Vlaanderen) and to Limburg (in Friesland-Limburg, Terschelling-Limburg) were rendered incorrectly. I solved this problem by replacing Zeeuws-Vlaanderen by Zaamslag (a village in the middle of the region) and Limburg by Roermond (in the middle of Limburg).

Name pairs were classified according to the positions of lines-in terms of compass point pairs-joining the locations concerned. Cardinal as well as ordinal compass points have been used. Locations on lines between NNW and NNE were counted as N, locations between NNE and ENE were counted as NE, etc.

Out of all LexisNexis occurrences, only (presumably) spontaneously invented locations have been included in this study, provided that they refer to the whole country indeed. This applies, for example, to name pairs in contexts like "De mensen komen overal vandaan, van Breskens tot Groningen" [The people [viz. visitors to a famous Amsterdam church] 
that come from everywhere, from Breskens to Groningen], or "Krantenjongens en -meisjes van Vaals tot Roodeschool" [Newspaper boys and girls from Vaals to Roodeschool". Name combinations in contexts dealing with companies, institutions, etc., based in various locations, have been omitted; in such cases, the writer may have felt the need to choose a location from those where the company or chain has its branches. This applies, for example, for the name pair in a text about theater: "op podia van Maastricht tot Groningen" [on stages from Maastricht to Groningen]. Neither have thematically connected name pairs been allowed, for example, "langs de hele kust, van Cadzand tot Schiermonnikoog" [alongside the whole coast, from Cadzand until Schiermonnikoog] has been neglected, both being coastal locations.

A few name pairs consist of toponyms with the initials A and Z, respectively (e.g. "van Amsterdam tot Zutphen"). These name combinations evoke the image of a list and, therefore, the concept of completeness, rather than the image of a long distance, and have been omitted in this study. The same applies to name pairs using alliteration ("van Dokkum tot Domburg") and rhyme ("van Zandvoort tot Montfoort").

One of the border toponyms is ambiguous: Groningen may refer to the province as well as the provincial capital. I tried to disambiguate this name, interpreting it as the city name if it was combined with settlement names, and as the province name wherever it was combined with the name of another province (e.g. Limburg), to a region or to waters. ${ }^{1}$

\section{Results}

244 name pairs have been found (see Table 1), in which 159 unique names occur. The latter encompass the following categories of geographic features:

a. 111 residential nuclei, like Maastricht,

b. 7 provinces, like Friesland,

c. 5 sub-provincial regions, like the Achterhoek (part of the province of Gelderland),

d. 5 islands (also being municipalities), like Schiermonnikoog,

e. 2 city quarters, like Amsterdam-Zuid,

f. 2 estuaries (Dollard, Westerschelde),

g. 1 former) municipality (not being one residential nucleus): Hemelumer Oldeferd,

h. 1 inland sea (Wadden Sea),

i. 1 place where three countries meet (Drielandenpunt).

\footnotetext{
${ }^{1}$ One can, however, not always be sure whether the province is meant or the city. For example, one of the sources combines the city of Leeuwarden with the province of Limburg ("van Limburg tot Leeuwarden"; see Trouw November 22, 2012; see LexisNexis); another source combines the city of Maastricht with the province of Drenthe (Parool January 20, 2005; see LexisNexis).
}

The longest measured distance is $329 \mathrm{~km}$ (Retranchement-Hongerige Wolf), the shortest one 30 (!) $\mathrm{km}$ (Volendam-Hilversum).

Eighteen names occur more than ten times (see Table 2; Fig. 4).

It would seem conceivable that the prototypicality of toponyms would more or less exactly correlate with their vicinity to the border. Some of the most prototypical items, however, are considerably more remote from the border (or from the North Sea coast) than less prototypical ones (see Tables 3, 4, 5; Figs. 5, 6, 7). To inventorize such less prototypical 'competitors' (parts of) circles were drawn from the starting points of lines through the 'target locations', for example, in the case of the pair Groningen-Maastricht, the circle would run through Maastricht, the 'target location'; the area south of the circle is thus beyond the target location. Maastricht then proves to be less southerly than, for example, the towns Vaals and Eijsden.

This raises the question, whether-if nuclei are involved-either the population or the news coverage is decisive. One might argue that the population is not an ideal criterium because it is doubtful whether the average 'naive' mind knows population figures. An argument in favor of news coverage is, on the other hand, that it takes account of, for example, scarcely populated locations that have, e.g. for touristic reasons, a large news coverage. The population may indeed be decisive with regard to, for example, Maastricht (pop. 122,000 inhabitants) and Eijsden (4000), and the same applies to the northern city of Groningen (pop. 216,000), less northerly, however, than Delfzijl $(25,000)$.

This argument is, however, contradicted by the case of Middelburg, in the southwestern part of the country (7 occurrences in name pairs; 47,000 inhabitants); south of Middelburg is Vlissingen (44,000 inhabitants, 6 occurrences in name pairs). Both cities also have about the same news coverage (see Table 4$).^{2}$

Possibly, Middelburg's status as a provincial capital made this city the most prototypical toponym in this part of the country. Provincial capitals get usually special attention in elementary school education and knowledge about them can have been at the root of many people's mental map. News coverage seems thus not a reliable predictor of prototypicality. This is confirmed by the case of, for example, Roodeschool, being number 10 on the prototypicality

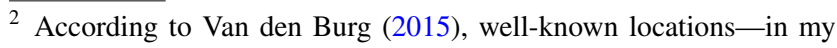
terms, locations having a large news coverage-are estimated closer than those which are known less. This does, however, not necessarily contradict my finding that the most peripheral locations in my data are well-known locations: in Van den Burg, subjects were presented with toponyms, while in the present study it is people who invent toponyms.
} 


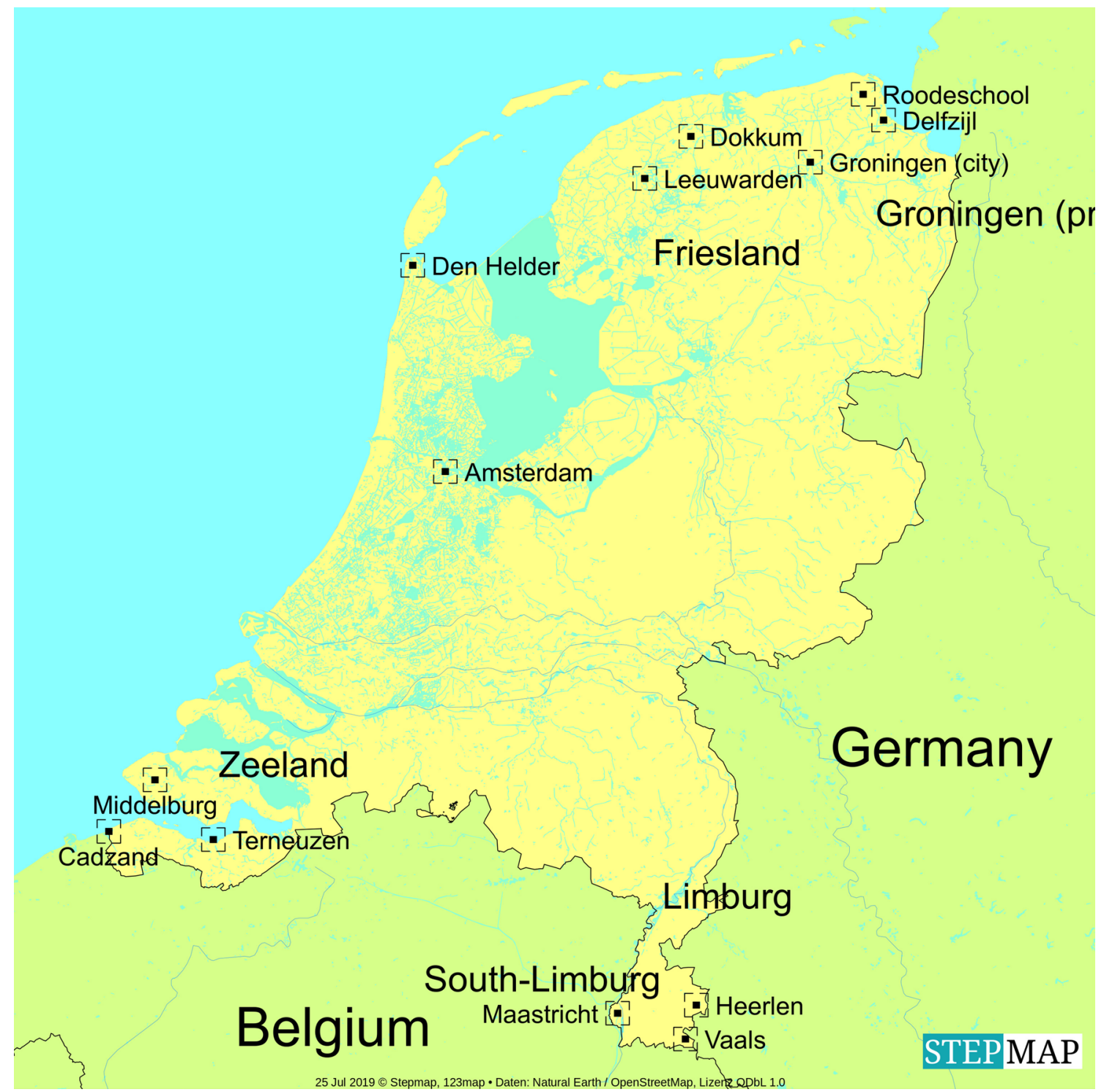

Fig. 4 Geographical position of the top-18 peripheral toponyms. Small letter size names refer to residential nuclei, large ones to provinces

Table 3 Maastricht and locations south of it (Source: LexisNexis Academic. Frequencies based on NRC Handelsblad 1-6-2013-3112-2015)

\begin{tabular}{llc}
\hline Toponym & Population & $\begin{array}{l}\text { Name frequency } \\
\text { in LexisNexis }\end{array}$ \\
\hline Drielandenpunt & - & 15 \\
Eijsden & 4000 & 23 \\
Gulpen & 3000 & 9 \\
Maastricht & 122,000 & 1280 \\
Vaals & 9000 & 41 \\
\hline
\end{tabular}

list but scoring no more than once in NexiLexis, while its 'competitor' Appingedam (not on that list) scores no less than 50 times.

Table 6 demonstrates a strong preference for the longitudinal directions, varying from $\mathrm{N}-\mathrm{S} / \mathrm{S}-\mathrm{N}$ to $\mathrm{NE}-\mathrm{SW} /$ SW-NE. Distances between name pairs running NE-SW/ SW-NE are, however, mostly longer than those between $\mathrm{N}-\mathrm{S}$ and S-N. For example, Delfzijl-the northernmost prototypical location-is situated $323 \mathrm{~km}$ from the southwesternmost location Cadzand (NE-SW), but $291 \mathrm{~km}$ from Vaals, the southernmost location (Fig. 8). This refutes the 
Table 4 Groningen and residential nuclei north of it (Source: LexisNexis Academic. Frequencies based on NRC Handelsblad 1-62013-31-12-2015)

\begin{tabular}{lrl}
\hline Toponym & Population & Name frequency in LexisNexis \\
\hline Appingedam & 12,000 & 50 \\
Delfzijl & 25,000 & 101 \\
Groningen (city) & 216,000 & Appr. $1320^{\mathrm{a}}$ \\
Hongerige Wolf & 100 & 9 \\
Nieuweschans & 1000 & 5 \\
Pieterburen & 300 & 16 \\
Roodeschool & 1300 & 1 \\
Uithuizen & 5000 & 7 \\
Uithuizermeeden & 2000 & 5 \\
Warfhuizen & 200 & - \\
Zoutkamp & 1000 & 11 \\
\hline
\end{tabular}

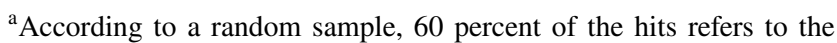
city (not the province) hypothesis that in oblong contoured countries there would be an absolute preference for the longest possible distance.

Furthermore, the data in Table 5 demonstrate a main preference for $\mathrm{N}-\mathrm{S} / \mathrm{N}-\mathrm{S}$ name combinations $(24 \times)$; NE-SW/ SW-NE score $14 \times$. This would suggest that the mental map prefers cardinal compass points to ordinal ones; below, however, a counter-argument will be presented (see Sect. 5).

As mentioned, name pairs in the categories E-W/W-E are absent in the top-18 list; this applies also to SE-NW/ NW-SE. On a lower level of prototypicality, however, such name pairs do occur. The $\mathrm{W}-\mathrm{E}$ combination, The Hague-Enschede, has been attested twice, other W-E combinations score each only once, and E-W combinations score each only once. The figure with regard to The Hague-Enschede, ranking highest in prototypicality, is too low to allow for the conclusion that there would be a preference for W-E.

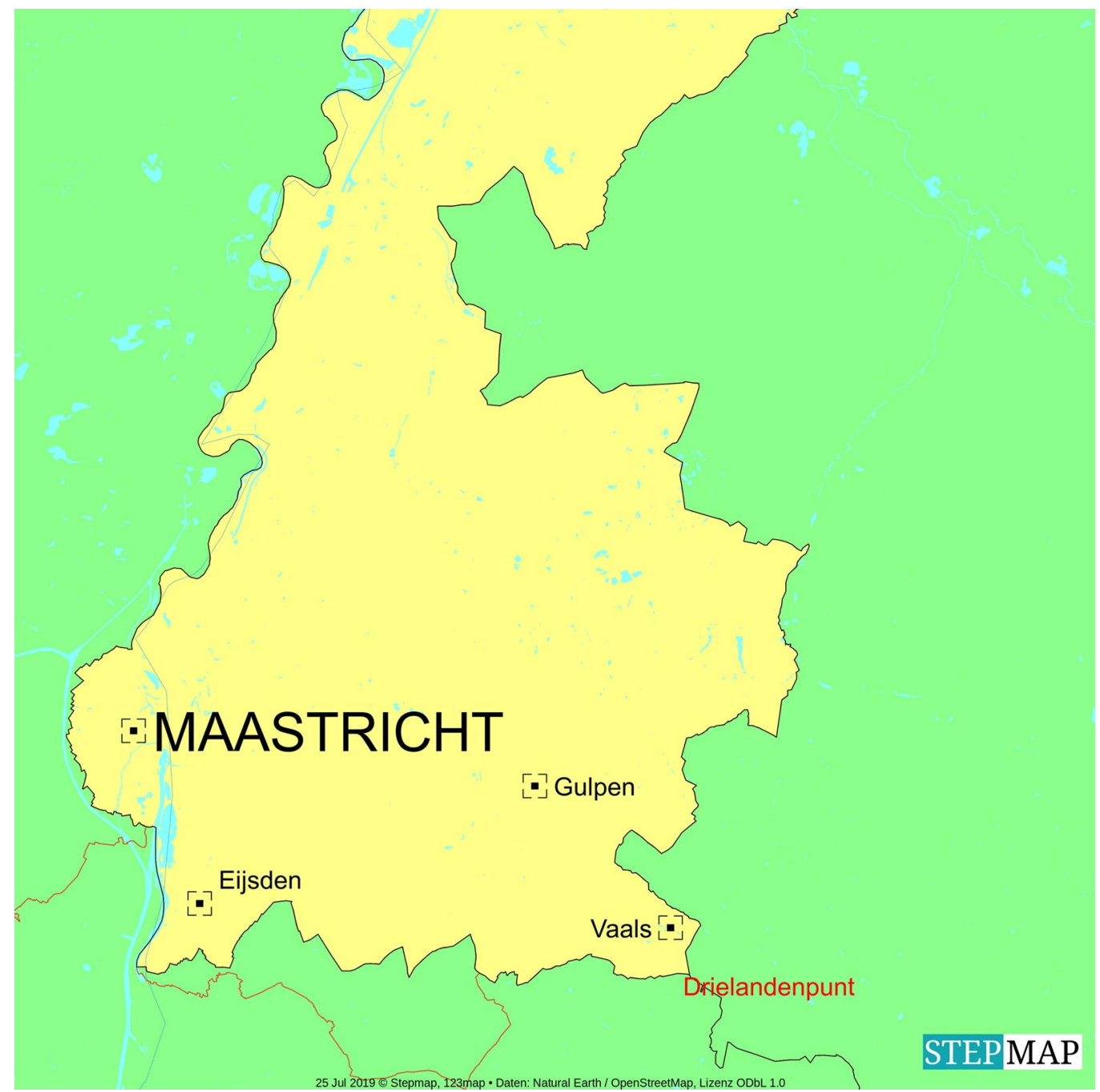

Fig. 5 Maastricht and 'competing' locations south of it 


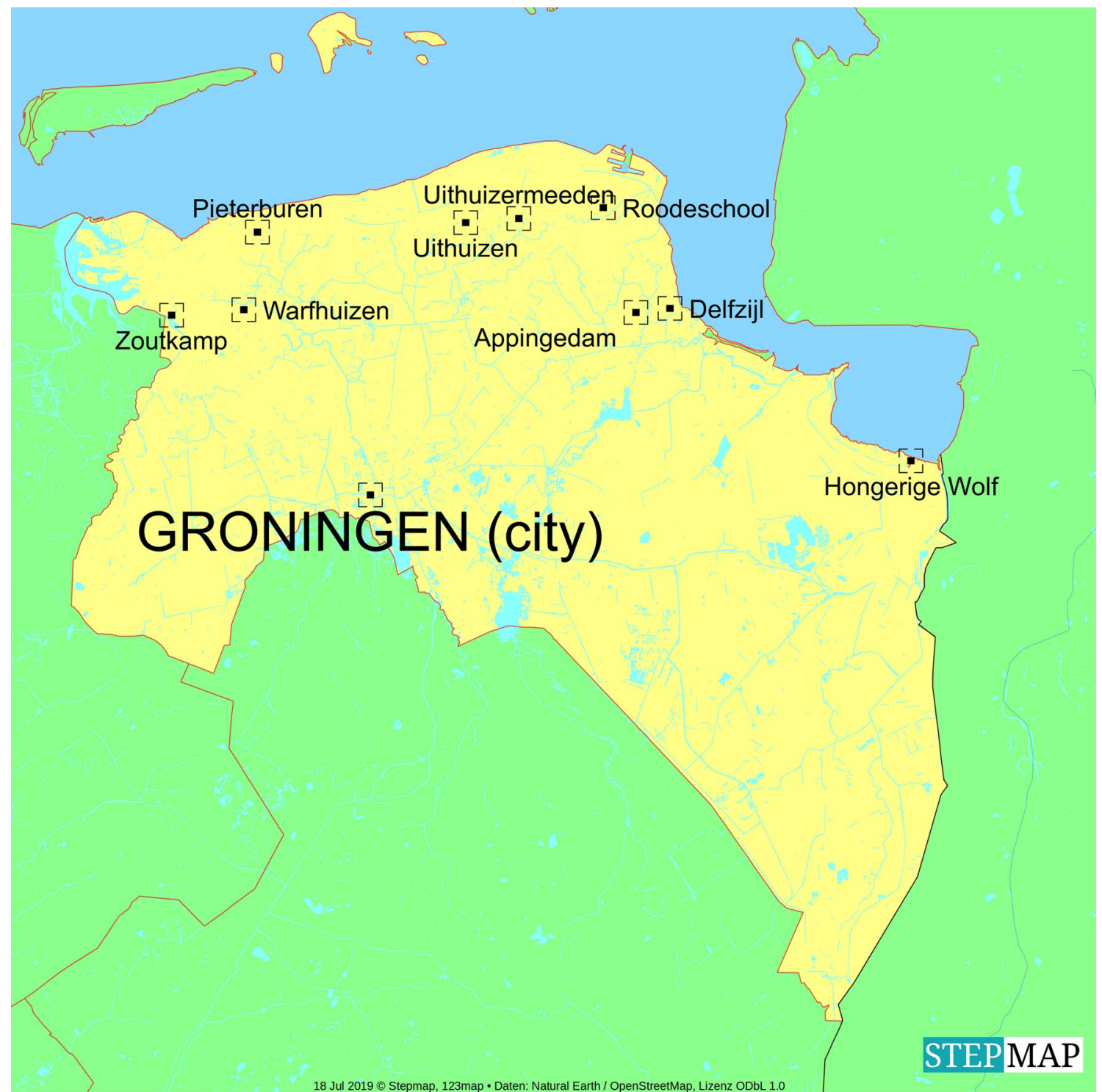

Fig. 6 Groningen and 'competing' nuclei north of it

Do the data show a clear preference in the name order within name pairs? One may expect that there is a tendency to prefer $\mathrm{N}-\mathrm{S}$ to $\mathrm{S}-\mathrm{N}$, considering the prominent position of the northern compass point. Table 7 refutes this: the sequence $\mathrm{N}-\mathrm{S}$ ranks $17 \times, \mathrm{S}-\mathrm{N} 18 \times$. However, the figures with regard to NE-SW/SW-NE attribute to the conclusion that there is a preference for $\mathrm{N}-\mathrm{S} / \mathrm{S}-\mathrm{N}$ in a broad sense (namely including NE-SW/SW-NE). The sequence NE-SW scores $3 \times$, while SW-NE name pairs are absent.

A highly surprising name as part from peripheral name combinations is Amsterdam. Nobody in the Netherlands would view the nation's capital as peripheral, although it is situated as few as $30 \mathrm{~km}$ from the North Sea. The questionable position of Amsterdam as part of a peripheral name pair must be due to its prominence as the national capital. If this hypothesis is correct, 'ubiquity' can also be expressed using a prominent toponym as one part of a name pair, contrasting with a purely 'remote' name, which makes one think of the abovementioned high status of provincial capitals.

None of the Wadden Islands (Texel, Vlieland, Terschelling, Ameland, Schiermonnikoog) is in the top-18. Two explanations-which do not exclude each other-are 


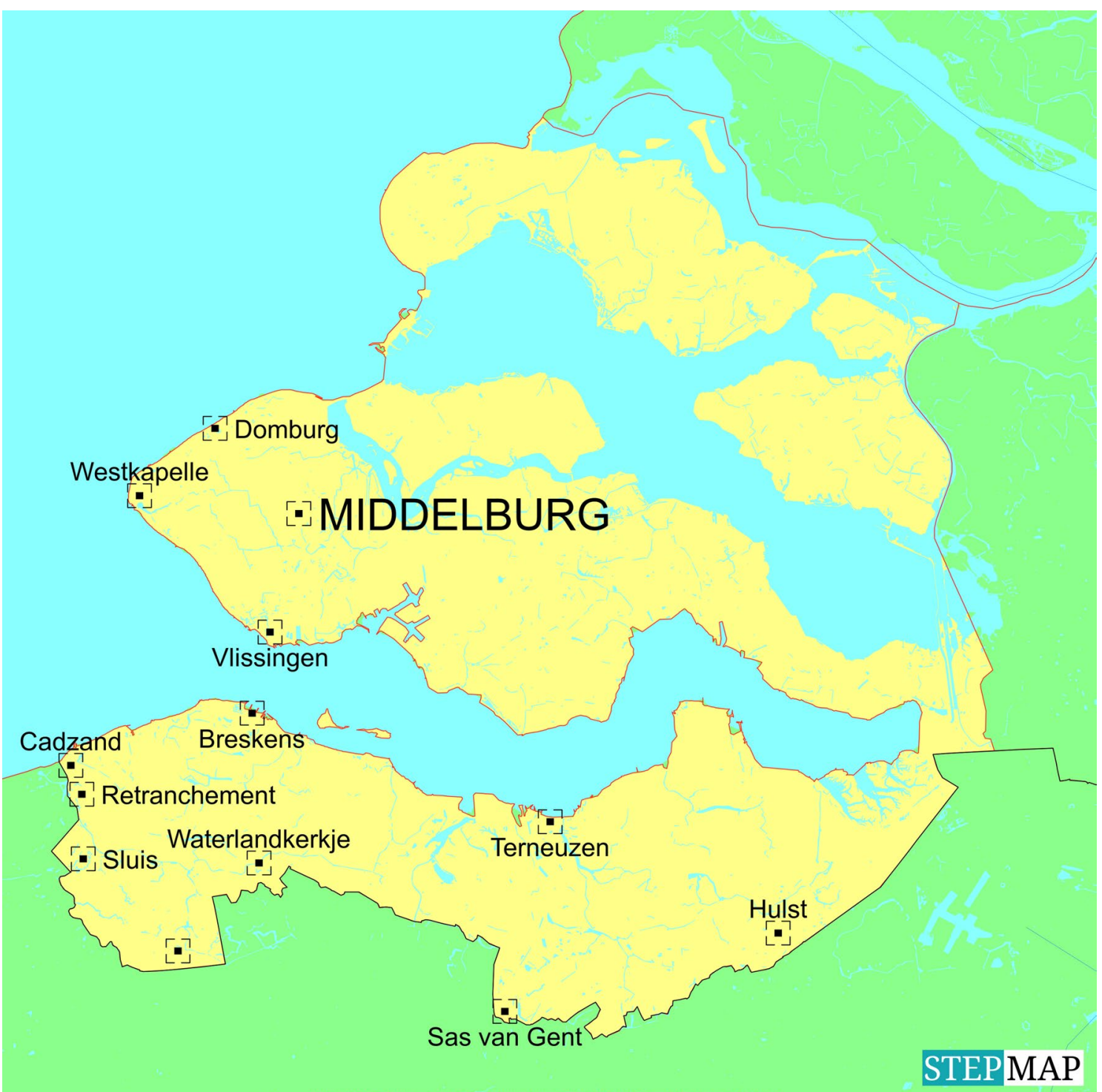

Fig. 7 Middelburg and 'competing' nuclei south of it

possible. First, the islands are not experienced as very remote from the Randstad perspective (apart from this, vicinity to the border/coast is not decisive, as we have seen): Randstad is the name for the crescent-shaped megalopolis in Western Holland with 7.1 million inhabitants which is the economical, cultural and political center of gravity in the country (Fig. 9). ${ }^{3}$ Second, the islands may not be experienced as highly essential parts of the country. In that connection, it is interesting to see that France is nicknamed L'Hexagone, and that in images, the 'hexagon' is rendered without Corsica or any other French island. Obviously, the mental map displays

\footnotetext{
3 There is no total consensus on the limits of the Randstad. On the geograhical perception of Randstad limits see Wakefield (1977).
}

a tendency to reduce country contours to a geometrical figure (Tversky 1981).

Reversely, the mental map may extend the country's contours by incorporating parts of adjoining countries that are sticking out. First, the results show that some connecting lines between name pairs run partly through Belgian territory, for example, in the name pairs Middelburg-Maastricht $(1 \times)$ and Amsterdam-Maastricht $(1 \times)$ (Fig. 10). An extreme example is Maastricht-Bergen op Zoom (90 percent running through Belgium!). Likewise, the line Groningen-Vaals runs partly through German territory. All this, too, points to the idea that the mental map simplifies the real situation.

Can the contours of the Netherlands be represented by a geometrical figure comparable with the French hexagon? The list of top-18 prototypical toponyms seems to confirm 
Table 5 Middelburg and locations south of it (Source: LexisNexis Academic. Frequencies based on NRC Handelsblad 1-6-2013-3112-2015)

\begin{tabular}{lrl}
\hline Toponym & Population & Frequency in LexisNexis \\
\hline Breskens & 4000 & 15 \\
Cadzand & 700 & 17 \\
Domburg & 1000 & 15 \\
Hulst & 10,000 & 141 \\
Middelburg & 47,000 & 169 \\
Retranchement & 400 & 1 \\
Sas van Gent & 3000 & 3 \\
Sluis & 2000 & 103 \\
Terneuzen & 25,000 & 56 \\
Vlissingen & 44,000 & 163 \\
Waterlandkerkje & 500 & - \\
Westkapelle & 2000 & 15 \\
\hline
\end{tabular}

this. If we discern (1) northern toponyms in the provinces of Groningen and Friesland as one angular point, Den Helder as a second point, Middelburg as the third one and Maastricht as the fourth one, this results in a quadrant (Fig. 11). If we would treat Groningen and Friesland as separate angular points, the contours would remain almost the same.

\section{Conclusions}

The data support the idea that 'naive' individuals possess a basic conscience with regard to the cartographic contours of a country like the Netherlands. The overwhelming majority of geographical features, deemed essential on the mental map if the concept of 'ubiquity' is involved, are residential nuclei. Research outside the Netherlands will have to prove

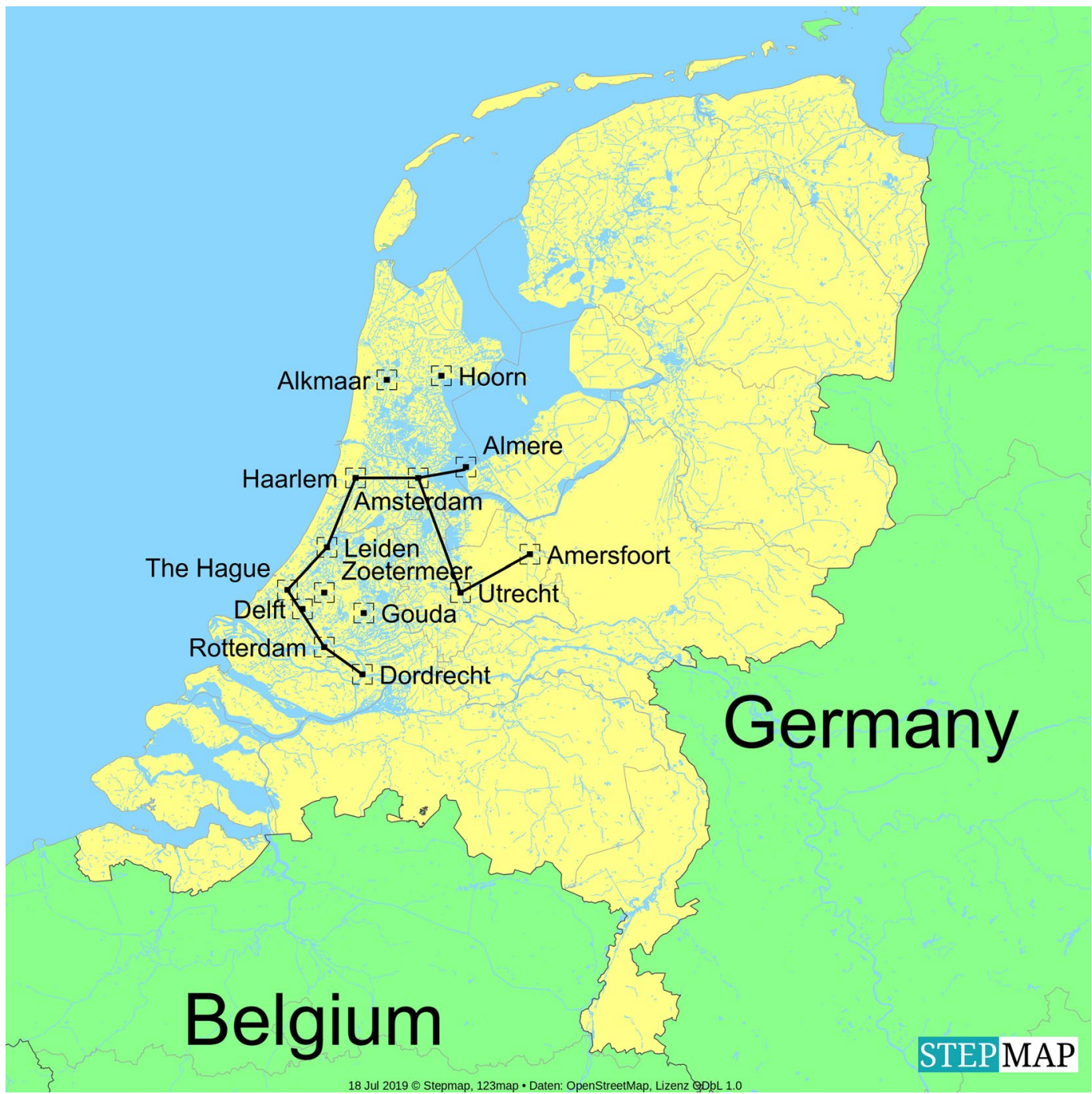

Fig. 8 North-South and Northeast-Southwest lines from Delfzij1 
Table 6 Positions of lines, in terms of compass point pairs, joining prototypical residential nuclei (based on top 18) and nuclei related with these (newspaper frequency $>1$ in the name pairs concerned)

\begin{tabular}{|c|c|c|c|c|c|c|}
\hline $\begin{array}{l}\text { Toponyms (belong- } \\
\text { ing to top } 18 \text { ) }\end{array}$ & $\begin{array}{l}\text { Occurring in } \\
\text { name pair(s) with }\end{array}$ & $\mathrm{N}-\mathrm{S} / \mathrm{S}-\mathrm{N}$ & $\begin{array}{l}\text { NE-SW/ } \\
\text { SW-NE }\end{array}$ & E-W/W-E & $\begin{array}{l}\text { SE-NW/ } \\
\text { NW-SE }\end{array}$ & Distance in $\mathrm{km}$ \\
\hline \multirow[t]{6}{*}{ 1. Maastricht } & Delfzijl & + & & & & 288 \\
\hline & Groningen (city) & + & & & & 270 \\
\hline & Den Helder & + & & & & 242 \\
\hline & Leeuwarden & + & & & & 261 \\
\hline & Terschelling & + & & & & 284 \\
\hline & Vlieland & + & & & & 271 \\
\hline \multirow[t]{6}{*}{ 2. Groningen (city) } & Goes & & + & & & 263 \\
\hline & Breda & & + & & & 220 \\
\hline & Kerkrade & + & & & & 264 \\
\hline & Maastricht & + & & & & 270 \\
\hline & Middelburg & & + & & & 277 \\
\hline & Terneuzen & & + & & & 280 \\
\hline \multirow[t]{7}{*}{ 3. Delfzijl } & Cadzand & & + & & & 323 \\
\hline & Maastricht & + & & & & 288 \\
\hline & Terneuzen & & + & & & 306 \\
\hline & Vaals & + & & & & 291 \\
\hline & Valkenburg & + & & & & 284 \\
\hline & Venlo & + & & & & 224 \\
\hline & Vlissingen & & + & & & 309 \\
\hline \multirow[t]{4}{*}{ 4. Den Helder } & Heerlen & + & & & & 244 \\
\hline & Kerkrade & + & & & & 185 \\
\hline & Maastricht & + & & & & 242 \\
\hline & Vaals & + & & & & 192 \\
\hline 5. Amsterdam & Maastricht & + & & & & 177 \\
\hline \multirow[t]{4}{*}{ 6. Roodeschool } & Retranchement & & + & & & 325 \\
\hline & Terneuzen & & + & & & 306 \\
\hline & Vaals & + & & & & 299 \\
\hline & Vlissingen & & + & & & 307 \\
\hline \multirow[t]{2}{*}{ 7. Leeuwarden } & Maastricht & + & & & & 261 \\
\hline & Middelburg & & + & & & 239 \\
\hline \multirow[t]{3}{*}{ 8. Vaals } & Delfzijl & + & & & & 291 \\
\hline & Den Helder & + & & & & 257 \\
\hline & Roodeschool & + & & & & 299 \\
\hline \multirow[t]{2}{*}{ 9. Dokkum } & Cadzand & & + & & & 280 \\
\hline & Maastricht & + & & & & 276 \\
\hline 10. Heerlen & Den Helder & + & & & & 244 \\
\hline
\end{tabular}

+ Applicable whether this is a general pattern (contrary to, for example, the hydronyms in the Deutschlandlied).

The results presented confront us with a major problem. Why are the province of Friesland and its towns Leeuwarden and Dokkum considerably lower in the top-18 list than Groningen (city), although Leeuwarden lies almost as far from Maastricht (nr. 1 on the top-18) as Groningen, with a difference of no more than $8 \mathrm{~km}$ ?
The solution of this problem may lie in the perspective from which the peripheral toponyms are chosen. Viewing that the corpus is based on national newspapers, it seems probable that the toponyms are mostly chosen by people living in the Randstad. From their perspective, Friesland is closer to home than Groningen. If this hypothesis is correct, it makes the Randstad itself part of the mental map. The Randstad perspective may also explain why Zeeland 


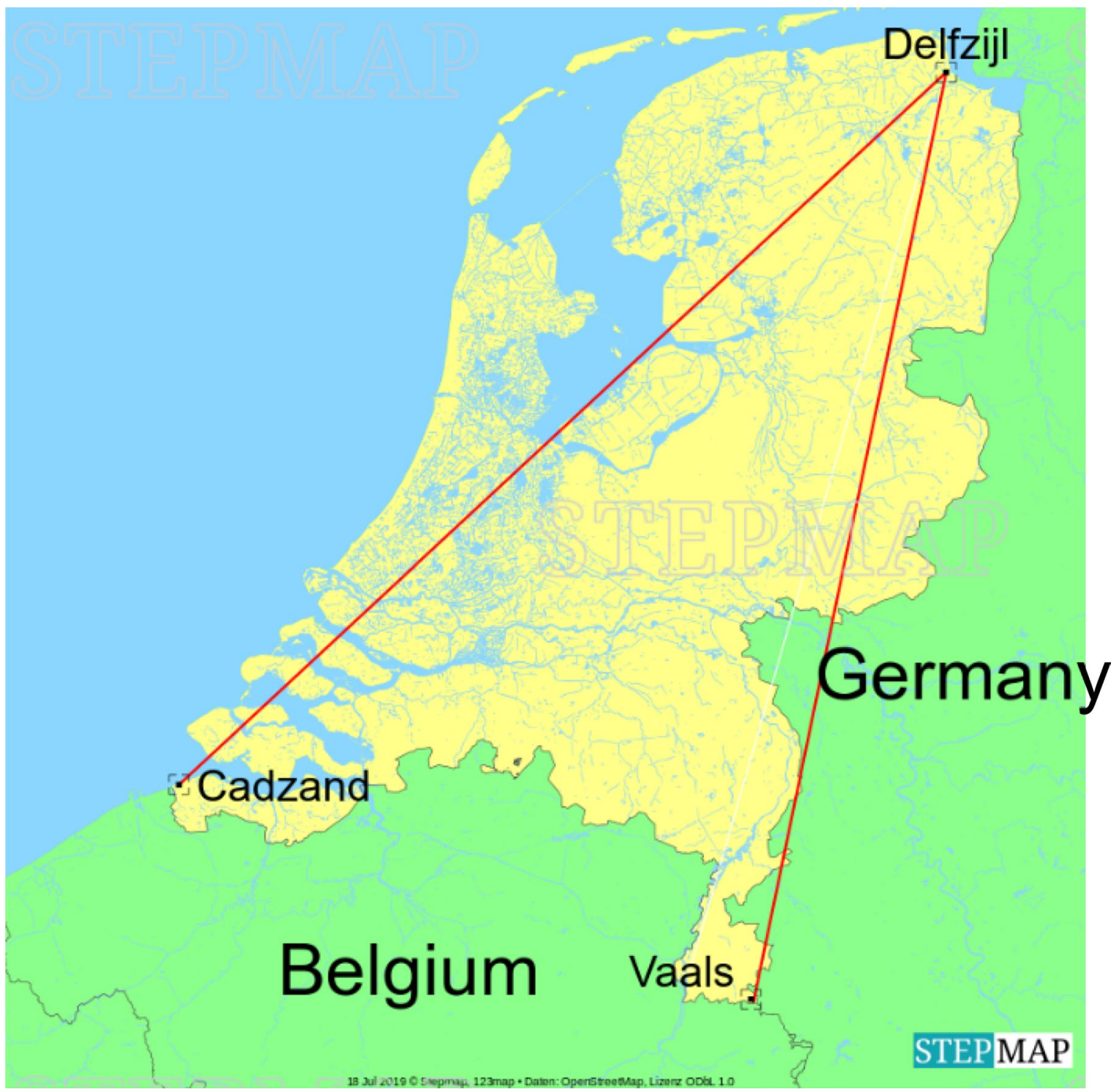

Fig. 9 North-South and Northeast-Southwest lines from Delfzijl

and its towns, too, rank much lower than Groningen (and even Friesland); Zeeland, too, is not experienced as very remote-from the Randstad, that is.

If we accept that the Randstad perspective is a correct assumption, it would, moreover, correct the suggestion, mentioned above (see Sect. 4), that the lower position of Zeeland and Middelburg on the list of prototypical names would be due to a preference on the mental map for cardinal compass points. As mentioned above (see Sect. 4), my hypothesis that, in an oblong country, the most prototypical toponyms are related to the longest distances has also been refuted, at least with regard to the Netherlands. The most prototypical locations are Maastricht and Groningen $(\mathrm{N}-\mathrm{S})$, but the distance between them is shorter than the one between, for example, Groningen-Middelburg (NE-SW) (Table 7).

If we, furthermore, accept the idea that distances between remote locations expressing ubiquity are primarily perceived from a Randstad perspective, but, furthermore, chosen based on their remoteness from the other location referred to in the name combination, this may also explain why-apart 


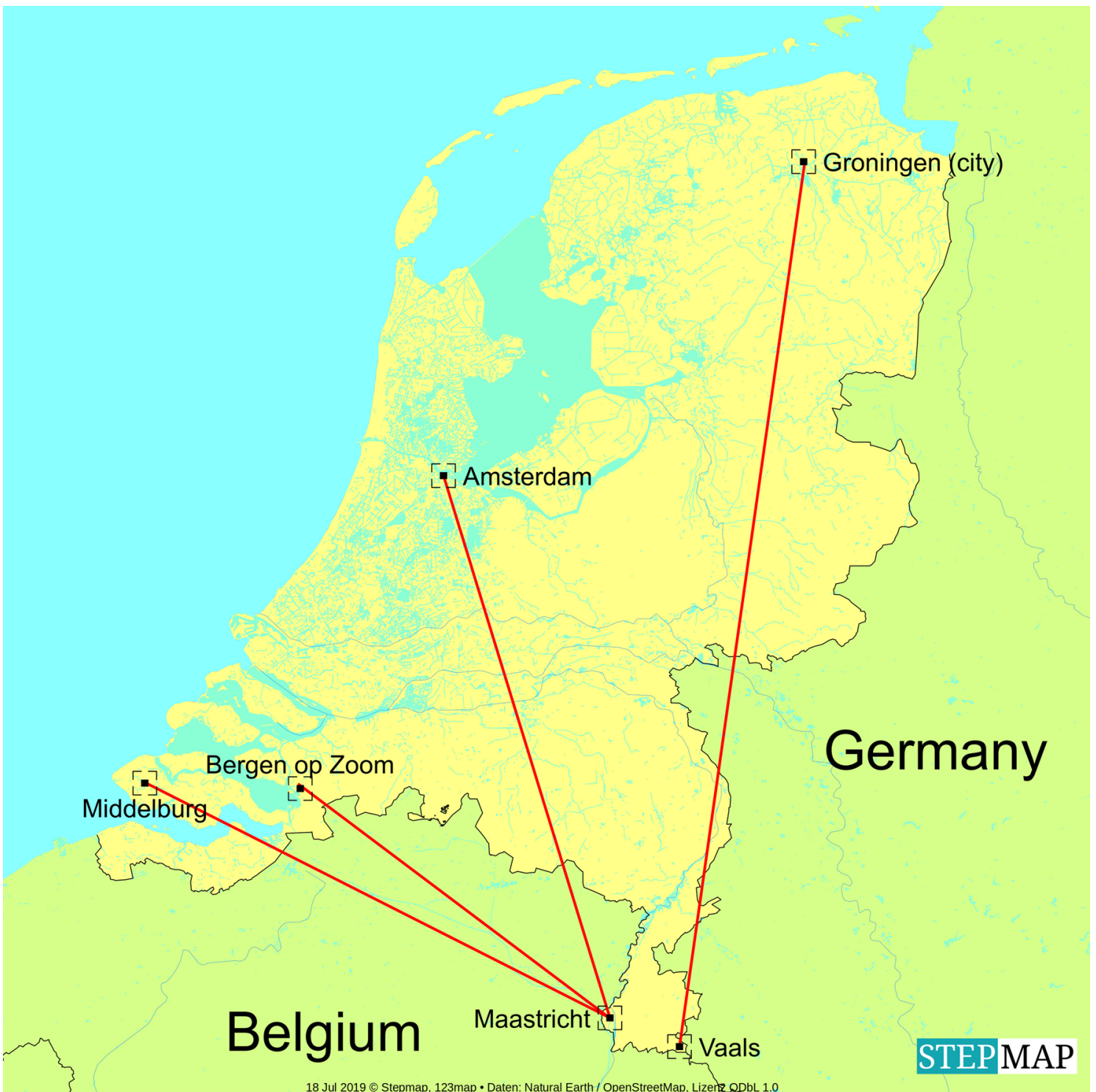

Fig. 10 Simplification by incorporating parts of adjoining countries

from the provincial capital criterium-prototypical toponyms are chosen within each 'remote' area. For example, Roodeschool, a tiny village, ranks relatively high on the list because it is the most northeastern location on the Dutch mainland, from the Randstad perspective.

The (doubtless mostly unconscious) process of choosing protopical toponyms may thus mostly encompass three stages: (1) choosing a region in the northern and southern parts of the country that are remote as well with regard to the Randstad as with regard to each other (Groningen region, South Limburg); (2) in each region concerned, the provincial capital in that region is chosen as the most prototypical location (Groningen, Leeuwarden, Maastricht). The only exception is Den Helder (province North Holland), Haarlem being the provincial capital (this city, $8 \mathrm{~km}$ from the North Sea coast, is not in the list of 18 most prototypical locations, 


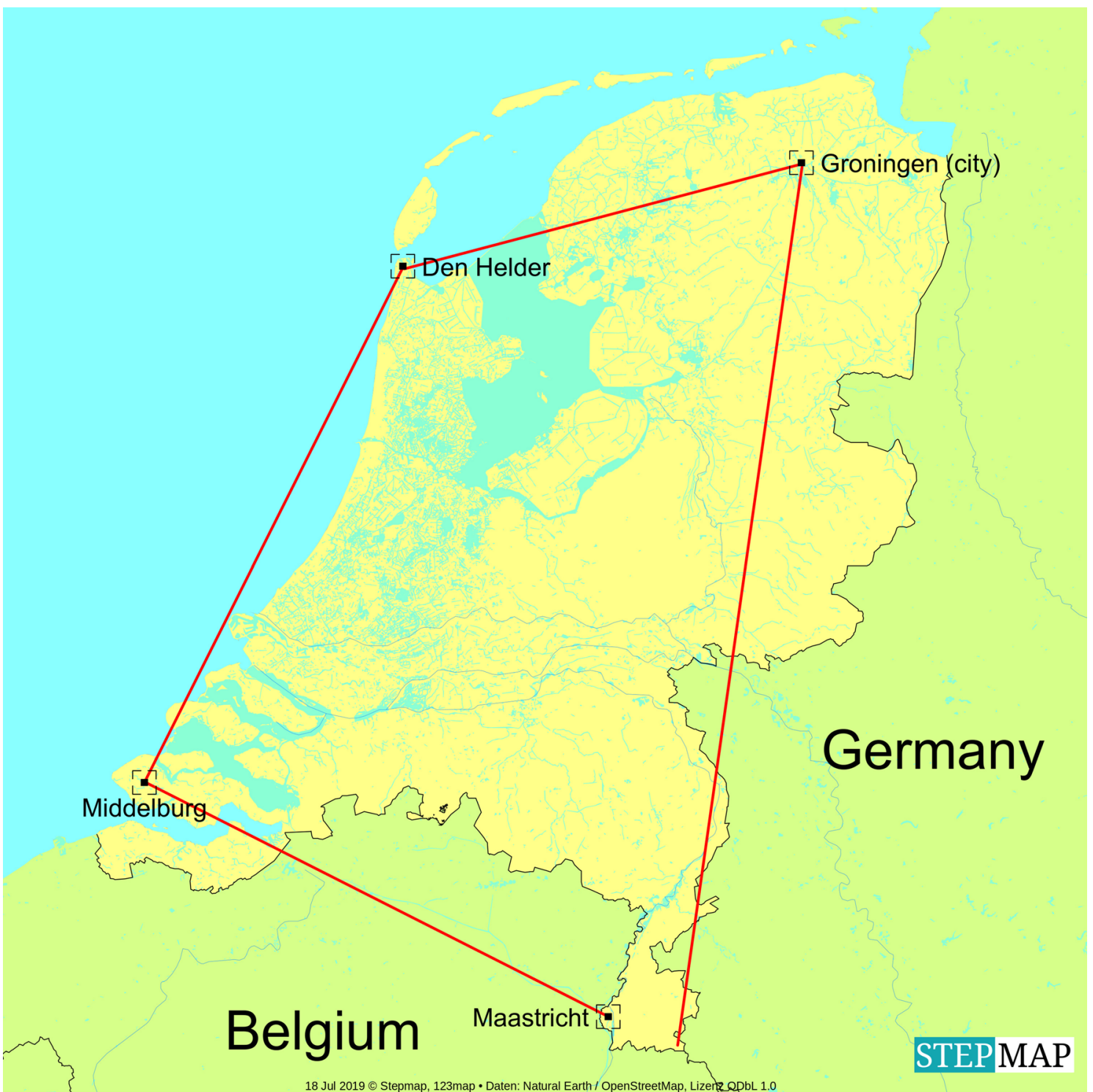

Fig. 11 The Netherlands, represented by a geometrical figure, based on prototypical toponyms

undoubtedly because it is part of the Randstad and is not felt as peripheral); (3) within each region, other (less prototypical) locations are chosen on condition that they (a) lie farther from the Randstad and (b) are more peripheral than the province's capital (Vaals, Terneuzen, Cadzand, Delfzijl, Roodeschool, Dokkum). Heerlen is an exception, here, lying more northerly than Maastricht and Vaals. 
Table 7 Name order frequencies in prototypical toponyms (based on top-18 and combinations with these)

\begin{tabular}{|c|c|c|c|c|c|c|c|}
\hline $\begin{array}{l}\text { Initial position within } \\
\text { name combination }\end{array}$ & $\begin{array}{l}\text { Corresponding } \\
\text { final toponym }\end{array}$ & $\mathrm{N}-\mathrm{S}$ & $\mathrm{S}-\mathrm{N}$ & NE-SW & SW-NE & E-W & W-E \\
\hline \multirow[t]{6}{*}{ 1. Maastricht } & Delfzijl & & + & & & & \\
\hline & Groningen (city) & & + & & & & \\
\hline & Den Helder & & + & & & & \\
\hline & Leeuwarden & & + & & & & \\
\hline & Terschelling & & + & & & & \\
\hline & Vlieland & & + & & & & \\
\hline \multirow[t]{6}{*}{ 2. Groningen (city) } & Goes & & & + & & & \\
\hline & Breda & & & + & & & \\
\hline & Kerkrade & + & & & & & \\
\hline & Maastricht & + & & & & & \\
\hline & Middelburg & & + & & & & \\
\hline & Terneuzen & & & + & & & \\
\hline \multirow[t]{7}{*}{ 3. Delfzijl } & Cadzand & & + & & & & \\
\hline & Maastricht & + & & & & & \\
\hline & Terneuzen & & + & & & & \\
\hline & Vaals & + & & & & & \\
\hline & Valkenburg & + & & & & & \\
\hline & Venlo & + & & & & & \\
\hline & Vlissingen & & + & & & & \\
\hline \multirow[t]{4}{*}{ 4. Den Helder } & Heerlen & + & & & & & \\
\hline & Kerkrade & + & & & & & \\
\hline & Maastricht & + & & & & & \\
\hline & Vaals & + & & & & & \\
\hline 5. Amsterdam & Maastricht & + & & & & & \\
\hline \multirow[t]{4}{*}{ 6. Roodeschool } & Retranchement & & + & & & & \\
\hline & Terneuzen & & + & & & & \\
\hline & Vaals & + & & & & & \\
\hline & Vlissingen & & + & & & & \\
\hline \multirow[t]{2}{*}{ 7. Leeuwarden } & Maastricht & + & & & & & \\
\hline & Middelburg & & + & & & & \\
\hline \multirow[t]{3}{*}{ 8. Vaals } & Delfzijl & + & & & & & \\
\hline & Den Helder & + & & & & & \\
\hline & Roodeschool & + & & & & & \\
\hline \multirow[t]{2}{*}{ 9. Dokkum } & Cadzand & & & & & & \\
\hline & Maastricht & + & & & & & \\
\hline 10. Heerlen & Den Helder & & + & & & & \\
\hline
\end{tabular}

+ Applicable
Open Access With the author(s)' decision to opt for Open Choice the copyright of the article changed in December 2019 to () The Author(s) 2019 and the article is forthwith distributed under the terms of the Creative Commons Attribution 4.0 International License (http://creativecommons.org/licenses/by/4.0/), which permits use, sharing, adaptation, distribution and reproduction in any medium or format, as long as you give appropriate credit to the original.

\section{References}

Burg van den AG (2015). Mental maps-een kwantitatief onderzoek naar stereotype beelden en de ruimtelijke perceptie van afstanden van Oost- en Zuid-Europese steden [Mental maps-A quantitative inquiry into stereotypical images and the spatial perception of distances of East and South European cities], file:///C:/Users/ Gebruiker/Downloads/Masterthesis\%20Geo-communicatie\%20 (2).pdf

Cadwallader Martin T (1976) Cognitive distance in intraurban space. In: Moore Gary T, Golledge Reginald G (eds) Environmental knowing - theories, research, and methods. Dowden, Hutchinson \& Ross, Stroudsburg, pp 16-24 
Downs RM, Stea D (eds) (1973) Image and environment: cognitive mapping and spatial behavior. Aldine Publishing Co, Chicago

Kitchin RM, Stewart Fotheringham A (1997) Aggregation issues in cognitive mapping. Prof geogr J Am geogr 49:269-279

LexisNexis Academic, http://academic.lexisnexis.eu/. Accessed 10 Mar 2019

MacEachren AM (1980) Travel time as the basis of cognitive distance. Prof Geogr 32:30-36

Maki RH et al (1977) Processing locational and orientational information. Mem Cognit 5:602-612

Pocock D, Hudson R (1978) Images of the urban environment. Macmillan, London
Sadalla EK et al (1980) Reference points in spatial cognition. J Exp Psychol Hum Learn Mem 6:526-528

Tversky B (1981) Distortions in memory for maps. Cognit Psychol 13:407-433

Wakefield VTJ (1977) The perception of Randstad Holland. Tijdschrift voor economische en sociale geografie 68:110-114

Walmsley DJ, Lewis GJ (1993) People and environment. Behavioural approaches in human geography, 2nd edn. Longman Scientific \& Technical, Harlow 